\title{
Neutrophil-related cytokines and neutrophil products in bronchoalveolar lavage fluid of a patient
}

\author{
H. Mukae*, N. Matsumoto*, J. Ashitani*, H. Mashimoto*, J. Kadota**, \\ M. Nakazato*, S. Kohno**, S. Matsukura*
}

Neutrophil-related cytokines and neutrophil products in bronchoalveolar lavage fluid of a patient with ANCA negative Wegener's granulomatosis. H. Mukae, N. Matsumoto, J. Ashitani, H. Mashimoto, J. Kadota, M. Nakazato, S. Kohno, S. Matsukura. CERS Journals Ltd 1996.

ABSTRACT: We report a case of Wegener's granulomatosis (WG), with neutrophil accumulation in bronchoalveolar lavage fluid (BALF).

Peripheral blood neutrophilia was present but the anti-neutrophil cytoplasmic antibody (ANCA) was negative. The serum and BALF levels of neutrophil-related cytokines, including interleukin (IL)-8, granulocyte colony-stimulating factor (GCSF) and IL-1 $\beta$, were increased, particularly in BALF. Plasma and BALF levels of neutrophil elastase and defensins, which are released by neutrophils and are potentially toxic to cells, were also elevated.

Our findings suggest that neutrophils and neutrophil-related cytokines may play an important role in the pathogenesis of anti-neutrophil cytoplasmic antibody negative as well as anti-neutrophil cytoplasmic antibody positive Wegener's granulomatosis.

Eur Respir J., 1996, 9, 1950-1954.
*The Third Dept of Internal Medicine, Miyazaki Medical College, Miyazaki, Japan. **The Second Dept of Internal Medicine, Nagasaki University School of Medicine, Nagasaki, Japan.

Correspondence: H. Mukae

The Third Dept of Internal Medicine Miyazaki Medical College

Kiyotake

Miyazaki

Japan 889-16.

Keywords: Defensins, interleukin-8, neutrophils, neutrophil elastase, Wegener's granulomatosis

Received: June 231995

Accepted after revision March 251996
Wegener's granulomatosis (WG) is a clinicopathological entity characterized by a necrotizing granulomatous vasculitis capable of affecting all organs, particularly the upper and lower respiratory tracts $[1,2]$. Although the pathogenesis of WG is poorly understood, recent reports have indicated that the anti-neutrophil cytoplasmic antibody (ANCA) is specific for establishing the diagnosis of WG and that its titre reflects disease activity [3, 4]. Furthermore, ANCA is known to cause neutrophil degranulation, resulting in the production of oxygen radicals in vitro [5]. WG is also characterized by intrapulmonary accumulation of neutrophils [6]. These findings suggest that neutrophils, probably activated by ANCA, may play an important role in the pathogenesis of this disease. However, a number of ANCA negative cases with active WG have also been reported [3, 4]. We present a case of active WG with accumulation of neutrophils in bronchoalveolar lavage fluid (BALF) and negative ANCA.

\section{Case report}

A 62 year old man was admitted to our hospital because of fever, cough and dyspnoea. Following consultation with a family physician due to a febrile episode 1 month prior to the present admission, right lung infiltration was observed on a chest roentgenogram and computed tomograph. A diagnosis of pneumonia was made and antibiotics were administered. However, the symptoms did not change. Repeated chest roentgenograms showed extensive spread of densities in both lungs.

The patient was referred to our hospital for further investigation and treatment. He was an ex-smoker, but his past and family histories were not remarkable. On admission, his height was $172 \mathrm{~cm}$, body weight $82 \mathrm{~kg}$, body temperature $38.4^{\circ} \mathrm{C}$, pulse rate 138 beats. $\mathrm{min}^{-1}$, and blood pressure $140 / 78 \mathrm{mmHg}$. Pitting oedema on the limbs and palatal petechiae were noted. Clinical examination of the chest revealed coarse crackles present at the lower part of the back of the chest, but no cyanosis, anaemia or jaundice.

The initial laboratory data included: C-reactive protein of $52.8 \mathrm{mg} \cdot \mathrm{dL}^{-1}$; red blood cell count of $4.24 \times 10^{-6}$ cells $\cdot \mathrm{mm}^{-3}$; haemoglobin of $12.9 \mathrm{~g} \cdot \mathrm{dL}^{-1}$; and white blood cell count (WBC) of $28.6 \times 10^{9}$ cells $\cdot \mathrm{L}^{-1}$, with $95.7 \%$ neutrophils, $3 \%$ lymphocytes, $1 \%$ monocytes and $0.3 \%$ eosinophils. Biochemical tests revealed elevated levels of serum lactic dehydrogenase (LDH) (466 IU.L-1), gammaglobulin $(34.2 \%)$ and reduced levels of total protein (5.87 $\left.\mathrm{g} \cdot \mathrm{dL}^{-1}\right)$ and albumin $\left(1.87 \mathrm{~g} \cdot \mathrm{dL}^{-1}\right)$. Blood urea nitrogen and creatine levels were normal, whilst urine examination showed \pm for protein and ++ for glucose. Sputum cytological examination showed no malignant cells, and repeated sputum cultures were negative for bacterial or fungal growth. Arterial blood gas analysis during $\mathrm{O}_{2}$ breathing $\left(2.0 \mathrm{~L} \cdot \mathrm{min}^{-1}\right)$ showed an arterial oxygen tension $\left(\mathrm{Pa}_{\mathrm{a}} \mathrm{O}_{2}\right)$ of $7.5 \mathrm{kPa}(56 \mathrm{mmHg})$, arterial carbon dioxide tension $\left(\mathrm{Pa}_{\mathrm{a}} \mathrm{CO}_{2}\right) 5.2 \mathrm{kPa}(39 \mathrm{mmHg})$, and $\mathrm{pH} 7.49$. 


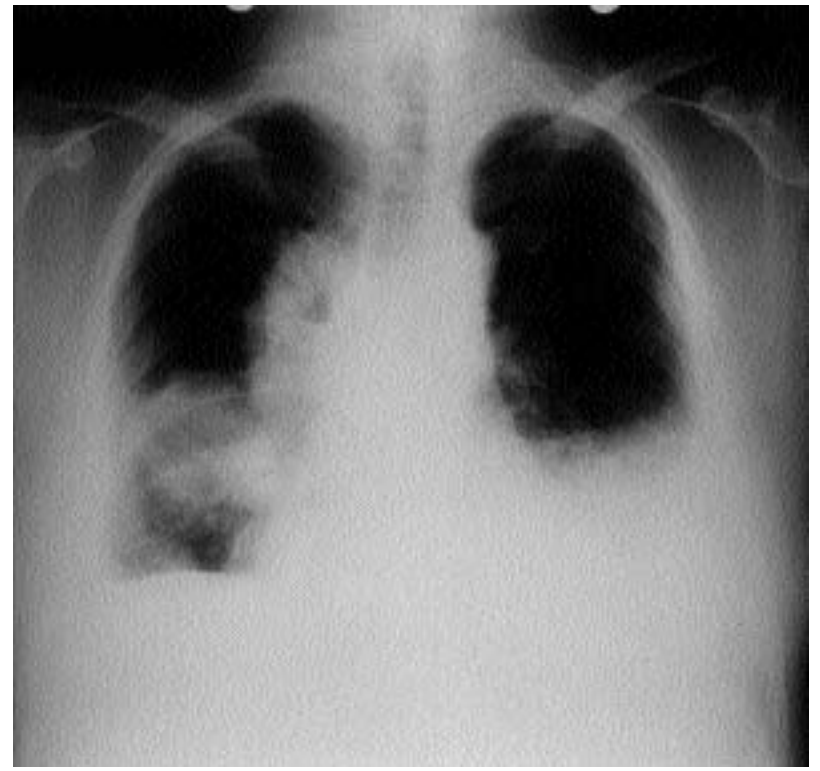

Fig. 1. - Chest roentgenogram on admission, showing dense infiltrates and pleural effusion in both lungs.

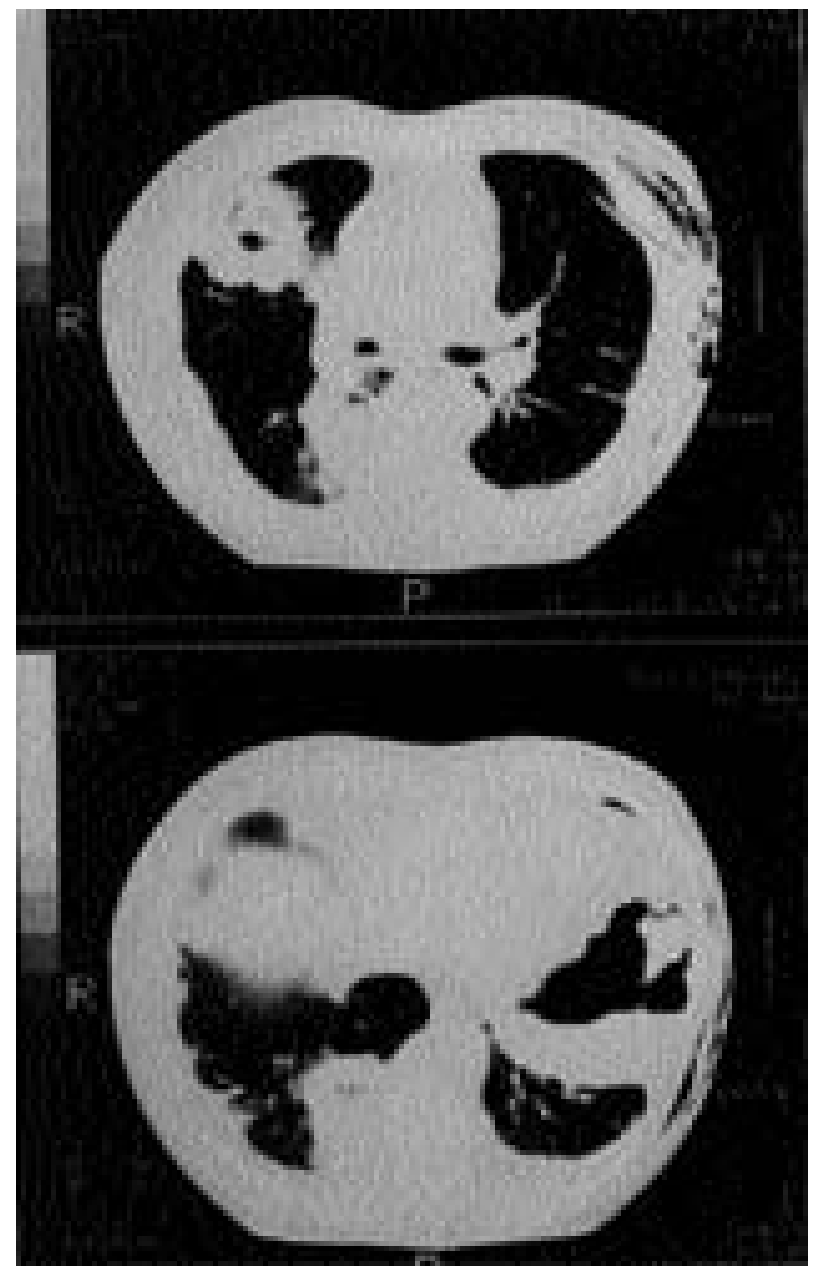

Fig. 2. - Chest computed tomography on the eighth day of hospitalization, showing multiple mass-like consolidations, with cavitation in both lungs. A chest drainage tube was inserted in the left thorax to reduce a pneumothorax. a)

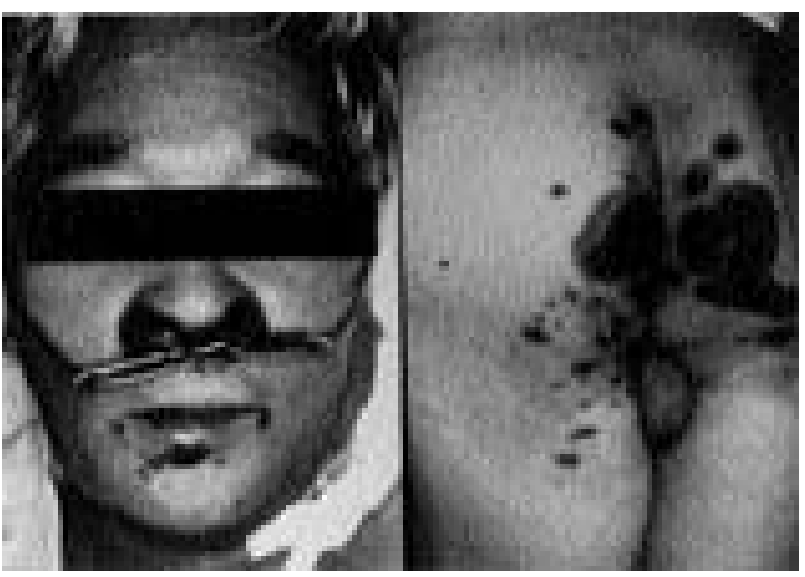

Fig. 3. - Erythema and irregularly sized haemorrhagic areas of skin necrosis appeared: a) on the mucosa of nasal and oral cavity and lips; and $b$ ) on the limbs and gluteal regions.

Chest roentgenogram (fig. 1) and computed tomography (fig. 2) demonstrated dense infiltrates, with cavitation in both lungs and bilateral pleural effusion. Serum ANCA was negative based on the enzyme-linked immunosorbent assay (ELISA) kit (Euro-Diagnostica AB, Ideon, Sweden). On the first day of hospitalization, bronchoscopic examination revealed marked stenoses from the subglottic region to the segmental bronchi bilaterally, together with mucosal erosions and ulcerations. Bronchoalveolar lavage (BAL) was performed as described previously [7]. A sample of BALF from the right middle lobe contained a high number of cells $\left(5.43 \times 10^{5}\right.$ cells $\left.\cdot \mathrm{mL}^{-1}\right)$ and increased neutrophils (neutrophils $79 \%$, alveolar macrophages $20 \%$, lymphocytes $1 \%$ ). BALF was also negative for ANCA.

Microscopic examination of endotracheal biopsy specimens showed a mixture of fibrin and necrotic debris, but no acid-fast bacilli, fungi, or malignant cells were detected on cytological examination. Cultures of bronchial washings yielded no bacteria or fungal growth.

Intravenous methylprednisolone therapy $\left(1.0 \mathrm{~g} \cdot \mathrm{day}^{-1}\right)$ was initiated on the first day of hospitalization and continued for 4 days, but erythema and irregularly-shaped haemorrhagic areas appeared on the skin of limbs and gluteal regions, and on the mucosa of nasal and oral cavity and lips (fig. 3). On the second day of hospitalization, pleural aspiration of $20 \mathrm{~mL}$ showed sterile serohaemorrhagic exudate, containing white blood cells with predominance of neutrophils (protein $2.9 \mathrm{~g} \cdot \mathrm{dL}^{-1}$; glucose $152 \mathrm{mg} \cdot \mathrm{dL}^{-1}$; LDH 4,630 IU.L $\mathrm{L}^{-1}$ ), but no organisms or malignant cells were identified. A left pneumothorax developed on the third day of hospitalization necessitating insertion of a chest drainage tube for water-sealed drainage. It was thought that the pneumothorax was secondary to thoracocentesis. Microscopic examination of biopsy specimens obtained from the nasal mucosa showed epithelioid granulomas and necrotizing vasculitis, with destruction of the arterial wall and neutrophil infiltrates (fig. 4a). These histological features were consistent with a diagnosis of WG. A further confirmation of diagnosis was made by demonstrating the presence of necrotizing vasculitis in skin biopsy specimens (fig. 4b). 
a)

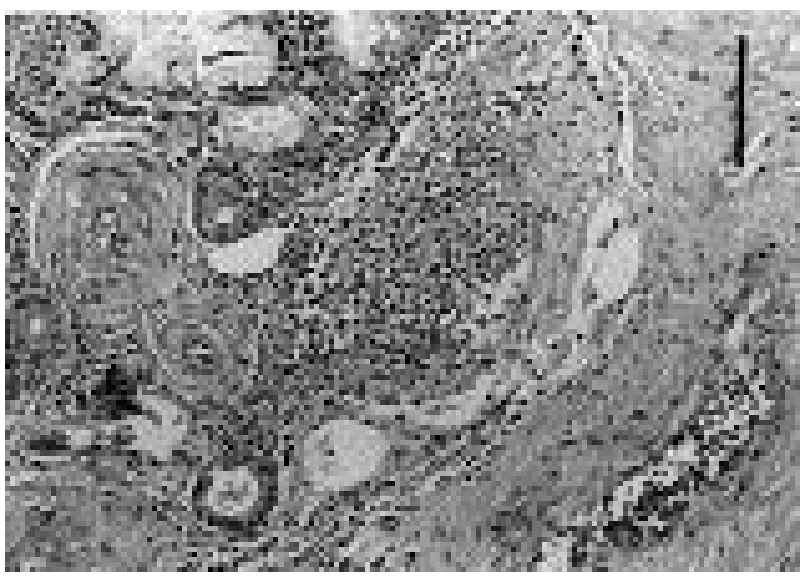

b)

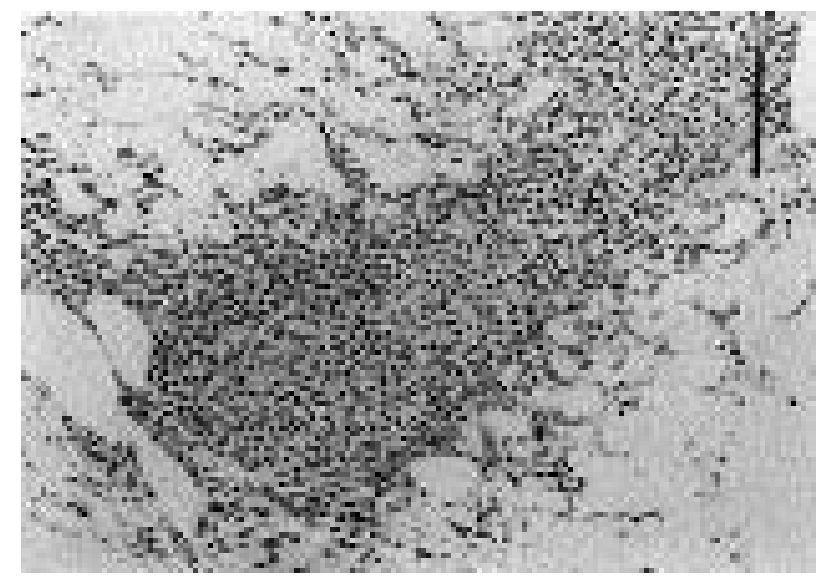

c)

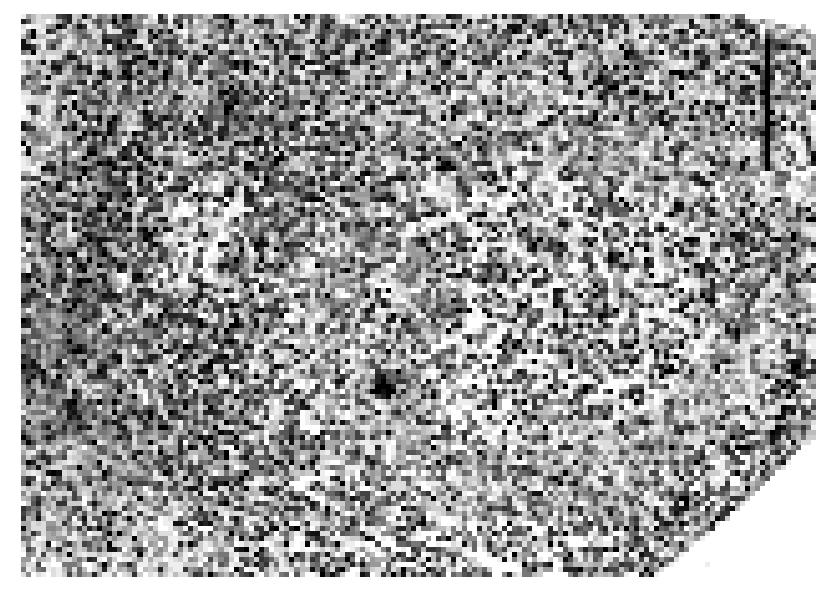

Fig. 4. - a) Poorly formed granulomas and neutrophil infiltration in a specimen from lesions on the nasal mucosa. b) Necrotizing vasculitis in a specimen from skin lesions. Note the characteristic transmural neutrophil infiltration. c) Granulomatous inflammation, consisting of multinucleated giant cells, histocytes and neutrophils, of the lung. (Haematoxylin and eosin staining). Internal scale bar $=100 \mu \mathrm{M}$.

Prednisolone (60 mg.day $\left.{ }^{-1}\right)$ and cyclophosphamide (100 $\mathrm{mg} \cdot$ day $\left.^{-1}\right)$ therapy was initiated on the fifth day of hospitalization, which improved symptoms and caused healing of the dermal and mucosal lesions. However, the
Table 1. - Neutrophil count and levels of mediators in the BALF and serum or plasma of the patient under investigation

\begin{tabular}{lcc}
\hline $\begin{array}{l}\text { Neutrophils and } \\
\text { mediators }\end{array}$ & Sample & Level \\
\hline WBC & Blood & $28.6 \times 10^{9} \mathrm{cells} \cdot \mathrm{L}^{-1}$ \\
Neutrophils & Blood & $96 \%$ \\
Total cell & BALF & $5.4 \times 10^{5} \mathrm{cells} \cdot \mathrm{mL}^{-1}$ \\
Neutrophils & BALF & $79 \%$ \\
Albumin & BALF & $11 \mathrm{mg} \cdot \mathrm{dL}^{-1}$ \\
TNF- $\alpha$ & Serum & $<5 \mathrm{pg} \cdot \mathrm{mL}^{-1}$ \\
& BALF & $<5 \mathrm{pg} \cdot \mathrm{mL}^{-1}$ \\
IL-1 $\beta$ & Serum & $<10 \mathrm{pg} \cdot \mathrm{mL}^{-1}$ \\
& BALF & $86 \mathrm{pg} \cdot \mathrm{mL}^{-1}$ \\
IL-8 & Serum & $79.7 \mathrm{pg} \cdot \mathrm{mL}^{-1}$ \\
& BALF & $815 \mathrm{pg} \cdot \mathrm{mL}^{-1}$ \\
G-CSF & Serum & $74 \mathrm{pg} \cdot \mathrm{mL}^{-1}$ \\
& BALF & $37 \mathrm{pg} \cdot \mathrm{mL}^{-1}$ \\
Neutrophil elastase & Plasma & $1100 \mu \mathrm{g} \cdot \mathrm{L}^{-1}$ \\
& BALF & $320 \mu \mathrm{g} \cdot \mathrm{L}^{-1}$ \\
Defensins & Plasma & $3071 \mathrm{pg} \cdot \mathrm{\mu L}^{-1}$ \\
& BALF & $87 \mathrm{pg} \cdot \mu L^{-1}$ \\
\hline
\end{tabular}

BALF: bronchoalveolar lavage fluid; WBC: white blood cell count; TNF- $\alpha$ : tumour necrosis factor- $\alpha$; IL: interleukin; GCSF: granulocyte colony-stimulating factor.

patient died on the 14th day of hospitalization due to an acute episode of massive haemoptysis. The cause of the haemoptysis was not known and autopsy was not performed. However, due to the nature of the haemoptysis, it was probably due to a rupture of a major blood vessel. Histological examination of lung specimens obtained by a needle after death revealed necrotizing granulomatous lesions with giant cells and necrotizing angiitis in the lungs (fig. 4c).

The levels of BALF and serum or plasma neutrophilrelated cytokines and neutrophil products are shown in table 1. Interleukin (IL)-8, granulocyte colony-stimulating factor (G-CSF), neutrophil elastase and defensins were elevated in all samples, and IL- $1 \beta$ was also higher in BALF of this patient compared with that of seven healthy volunteers. The latter group consisted of two females and five males (mean \pm SD age $26 \pm 6$ yrs; two smokers and five nonsmokers). IL-8 (Tore Fuji Bionix, Tokyo, Japan) and tumour necrosis factor- $\alpha$ (TNF- $\alpha$ ) (Otsuka, Tokushima, Japan) levels were measured with ELISA. G-CSF levels were measured using a chemiluminescent immunoassay [8]. Neutrophil elastase was measured by enzyme immunoassay (Sanwa, Nagoya, Japan), and IL-1 $\beta$ levels were measured by radioimmunoassay (RIA) (Medgenix Diagnostics SA, Brussels, Belgium). In addition, defensin (human neutrophil peptides 1-3) levels were measured by RIA established by our group [9].

\section{Discussion}

The hypothesis that neutrophils play an important role in the pathogenesis of WG is supported by the interaction between these cells and ANCA, particularly the ability of ANCA to activate neutrophils [3-5]. In fact, a recent study examining BALF demonstrated the accumulation of neutrophils in the airway in ANCA positive patients with active WG [6]. Accumulation of neutrophils 
in the lung is thought to cause lung injury due to their oxidative and proteolytic products. Our study demonstrated accumulation of neutrophils in BALF and histopathological features of WG in a patient negative for ANCA. Based on these findings, we suggest that neutrophils may play an important role in the pathogenesis of ANCA negative as well as ANCA positive WG. To support our hypothesis, we studied the content of neutrophil-related cytokines and neutrophil products in BALF and serum or plasma of this patient.

IL-8 is known to have a potent neutrophil chemotactic activity [10], and to play an important role in the accumulation of neutrophils in the lungs in the adult respiratory distress syndrome (ARDS) [11], idiopathic pulmonary fibrosis (IPF) [12] and diffuse panbronchiolitis (DPB) [13, 14]. The concentrations of IL-8 in BALF $\left(815 \mathrm{pg} \cdot \mathrm{mL}^{-1}\right)$ and serum $\left(79.7 \mathrm{pg} \cdot \mathrm{mL}^{-1}\right)$ were higher in our patient compared with those of five of the seven healthy volunteers (BALF $21 \pm 46 \mathrm{pg} \cdot \mathrm{mL}^{-1}$; serum $2.5 \pm 5.6 \mathrm{pg} \cdot \mathrm{mL}^{-1}$ ) (table 1). More importantly, the levels of IL-8 in our patient were similar to those observed in DPB patients (BALF $375 \pm$ $462 \mathrm{pg} \cdot \mathrm{mL}^{-1}(\mathrm{n}=15)$; serum $\left.66.6 \pm 88.2 \mathrm{pg} \cdot \mathrm{mL}^{-1},(\mathrm{n}=12)\right)$ [14] and in ARDS patients [11]. Therefore, IL-8 may contribute, at least in part, to neutrophil accumulation in the lungs of patients with WG.

G-CSF is a primary cytokine capable of stimulating the proliferation and activation of neutrophils [15]. An elevated serum level of G-CSF (74 pg.mL-1) was also observed in our patient (table 1), compared with a concentration of $13.8 \pm 7.7 \mathrm{pg} \cdot \mathrm{mL}^{-1}$ measured in 116 normal Japanese individuals [8]. In addition, the level of G-CSF in BALF $\left(37 \mathrm{pg} \cdot \mathrm{mL}^{-1}\right)$ was higher in our patient than that detected in seven healthy volunteers (average $2.0 \mathrm{pg} \cdot \mathrm{mL}^{-1}$; range $\left.0-8 \mathrm{pg} \cdot \mathrm{mL}^{-1}\right)$.

IL- $1 \beta$ and TNF- $\alpha$ cause potent induction of IL- 8 by fibroblast and type II pneumocytes [16]. Elevated levels of serum TNF- $\alpha$ have also been reported in patients with active WG [17]. However, the serum levels of IL-1 $\beta$ and TNF- $\alpha$ and the BALF level of the latter were below the detection limit in our patient, whilst the BALF level of IL-1 $\beta\left(86 \mathrm{pg} \cdot \mathrm{mL}^{-1}\right)$ was higher compared with that of seven healthy volunteers $\left(22.6 \pm 4.8 \mathrm{pg} \cdot \mathrm{mL}^{-1}\right)$. In this respect, previous reports have demonstrated that, whereas BALF levels of these two cytokines are elevated during the early acute phase of ARDS, the level of TNF- $\alpha$ diminishes more markedly than that of IL- $1 \beta$ in the late phase $[18,19]$. Thus, it is possible that the presence of TNF- $\alpha$ in the serum at concentrations below the detection limit in our patient was due to the time of serum sampling. The serum sample was obtained from our patient approximately 1 month after the onset of symptoms.

Oxidative and proteolytic substances released by neutrophils, such as neutrophil elastase, have been reported to damage human cells [20-22]. In addition, defensins are major neutrophil peptides, constituting 30-50\% of the protein content of human azurophil granules, and are also known to damage human cells [23]. The levels of neutrophil elastase in plasma $\left(1,100 \mu \mathrm{g} \cdot \mathrm{L}^{-1}\right)$ and BALF $\left(320 \mu \mathrm{g} \cdot \mathrm{L}^{-1}\right)$ were elevated in our patient compared with those of normal subjects (plasma 16-54 $\mu \mathrm{g} \cdot \mathrm{L}^{-1}(\mathrm{n}=139)$; BALF below the detection limit of $10 \mu \mathrm{g} \cdot \mathrm{L}^{-1}(\mathrm{n}=7)$ ), whilst the BALF level of $\alpha_{1}$-antitrypsin in our patient $\left(4.1 \mathrm{mg} \cdot \mathrm{dL}^{-1}\right)$ was also higher than the control $(0-0.7$ $\left.\mathrm{mg} \cdot \mathrm{dL}^{-1} ; \mathrm{n}=7\right)$. Furthermore, defensins levels were also elevated in plasma $\left(3,071 \mathrm{pg} \cdot \mu \mathrm{L}^{-1}\right)$ and in BALF (87 $\mathrm{pg} \cdot \mu \mathrm{L}^{-1}$ ) compared with normal subjects (plasma $314.3 \pm$ $101.7 \mathrm{pg} \cdot \mathrm{LL}^{-1}$; BALF not detected in all subjects). These results suggest that elevated levels of these neutrophil products may damage lung cells and vessels in WG.

In conclusion, we have presented a case of active Wegener's granulomatosis with a high number of neutrophils, neutrophil-related cytokines and neutrophil products in the absence of serum and bronchoalveolar lavage fluid anti-neutrophil cytoplasmic antibody.

Acknowledgement: The authors thank F.G. Issa (WordMedex) for his assistance in reading and editing the manuscript.

\section{References}

1. Cordier JF, Valeyre D, Guillevin L, Loire R, Brechot JM. Pulmonary Wegener's granulomatosis: a clinical and imaging study of 77 cases. Chest 1990; 97: 906-912.

2. Hoffman GS, Kerr GS, Leavitt RY, et al. Wegener's granulomatosis: an analysis of 158 patients. Ann Intern Med 1992; 116: 488-498.

3. Nolle B, Specks U, Ludemann J, Rohrbach MS, DeRemee RA, Gross WL. Anticytoplasmic autoantibodies: their immunodiagnostic value in Wegener's granulomatosis. Ann Intern Med 1989; 111: 28-40.

4. Kerr GS, Fleisher TA, Hallahan CW, Leavitt RY, Fauci AS, Hoffman GS. Limited prognostic value of changes in antineutrophil cytoplasmic antibody titer in patients with Wegener's granulomatosis. Arthritis Rheum 1993; 36: 365-371.

5. Falk RJ, Terrell RS, Charles LA, Jennette JC. Anti-neutrophil cytoplasmic autoantibodies induce neutrophils to degranulate and produce oxygen radicals in vitro. Proc Natl Acad Sci USA 1990; 87: 4115-4119.

6. Hoffman GS, Sechler JMG, Gallin JI, et al. Bronchoalveolar lavage analysis in Wegener's granulomatosis: a method to study disease pathogenesis. Am Rev Respir Dis 1991; 143: 401-407.

7. Mukae H, Hirota M, Kohno S, et al. Elevation of tumorassociated carbohydrate antigens in patients with diffuse panbronchiolitis. Am Rev Respir Dis 1993; 148: 744751.

8. Kiriyama R, Chichibu K, Matsuno T, Ohsawa N. Sensitive chemiluminescent immunoassay for human granulocyte colony-stimulating factor (G-CSF) in clinical applications. Clin Chim Acta 1993; 220: 201-209.

9. Shiomi K, Nakazato M, Ihi T, Kanagawa K, Matsuo H, Matsukura S. Establishment of radioimmunoassay for human neutrophil peptides and their increases in plasma and neutrophil in infection. Biochem Biophys Res Commun 1993; 195: 1336-1344.

10. Baggiolini M, Walz A, Kunkel SL. Neutrophil-activating peptide-1/interleukin- 8 , a novel cytokine that activates neutrophils. J Clin Invest 1989; 84: 1045-1049.

11. Miller EJ, Cohen $\mathrm{AB}$, Nagao $\mathrm{S}$, et al. Elevated levels of NAP-1/interleukin-8 are present in the airspaces of patients with the adult respiratory distress syndrome and are associated with increased mortality. Am Rev Respir Dis 1992; 146: 427-432.

12. Lynch JP III, Standiford TJ, Rolfe MW, Kunkel SL, Strieter RM. Neutrophilic alveolitis in idiopathic pulmonary fibrosis: the role of interleukin-8. Am Rev Respir Dis 1992; 145: 1433-1439. 
13. Oishi K, Sonoda F, Kobayashi S, et al. Role of interleukin-8 (IL-8) and an inhibitory effect of erythromycin on IL-8 release in the airways of patients with chronic airway diseases. Infect Immun 1994; 62: 4145-4152.

14. Mukae H, Kadota J, Kohno S, et al. Increase in activated CD8+ cells in bronchoalveolar lavage fluid in patients with diffuse panbronchiolitis. Am J Respir Crit Care Med 1995; 152: 613-618.

15. Nomura H, Imazeki I, Oheda M, Kubota N, Tamura M, Ono M, Veyama Y, Asano S. Purification and characterization of human granulocyte colony-stimulating factor (G-CSF). EMBO J 1986; 5: 871-876.

16. Kunkel SL, Standiford T, Kasahara K, Strieter RM. Interleukin-8 (IL-8): the major neutrophil chemotactic factor in the lung. Exp Lung Res 1991; 17: 17-23.

17. Gross WL, Csernok E, Schmitt WH. Anti-neutrophil cytoplasmic autoantibodies: immunobiological aspects. Klin Wschr 1991; 69: 558-566.

18. Hyers TM, Tricomi SM, Dettenmeier PA, Fowler AA. Tumor necrosis factor levels in serum and bronchoalveolar lavage fluid of patients with the adult respiratory distress syndrome. Am Rev Respir Dis 1991; 144: 268- 271.
19. Suter PM, Suter S, Girardin E, Roux-Lombard P, Grau GE, Dayer J-M. High bronchoalveolar levels of tumor necrosis factor and its inhibitors, interleukin-1, interferon and elastase, in patients with adult respiratory distress syndrome after trauma, shock or sepsis. Am Rev Respir Dis 1992; 145: 1016-1022.

20. Cantin AM, North SL, Fells GA, Hubbard RC, Crystal RG. Oxidant-mediated epithelial cell injury in idiopathic pulmonary fibrosis. J Clin Invest 1987; 79: 16651673.

21. Snider GL, Lucey EC, Christensen TG, et al. Emphysema and bronchial secretory cell metaplasia induced in hamsters by human neutrophil products. Am Rev Respir Dis 1984; 129: 155-160.

22. Amitani R, Wilson R, Rutman A, et al. Effects of human neutrophil elastase and Pseudomonas aeruginosa proteinases on human respiratory epithelium. Am J Respir Cell Mol Biol 1991; 4: 26-32.

23. Okrent DG, Lichtenstein AK, Ganz T. Direct cytotoxicity of polymorphonuclear leukocyte granule proteins to human lung-derived cells and endothelial cells. Am Rev Respir Dis 1990; 141: 178-185. 